\title{
Article \\ Strategy of Compatible Use of Jet and Plunger Pump with Chrome Parts in Oil Well
}

\author{
Oleg Bazaluk ${ }^{1}$ (D), Olha Dubei ${ }^{2}$, Liubomyr Ropyak ${ }^{3}$, Maksym Shovkoplias ${ }^{3}$, Tetiana Pryhorovska ${ }^{4}$ \\ and Vasyl Lozynskyi ${ }^{5, *(D)}$
}

1 Belt and Road Initiative Institute for Chinese-European Studies (BRIICES), Guangdong University of Petrochemical Technology, Maoming 525000, China; bazaluk@ukr.net

2 Department of Petroleum Production, Ivano-Frankivsk National Technical University of Oil and Gas, 076019 Ivano-Frankivsk, Ukraine; olgadubej@gmail.com

3 Department of Computerized Engineering, Ivano-Frankivsk National Technical University of Oil and Gas, 076019 Ivano-Frankivsk, Ukraine; 1_ropjak@ukr.net (L.R.); maks.shovkoplias@gmail.com (M.S.)

4 Department of Engineering and Computer Graphics, Ivano-Frankivsk National Technical University of Oil and Gas, 076019 Ivano-Frankivsk, Ukraine; t.pryhorovska@nung.edu.ua

5 Department of Mining Engineering and Education, Dnipro University of Technology, 49005 Dnipro, Ukraine

* Correspondence: lvg.nmu@gmail.com

check for

updates

Citation: Bazaluk, O.; Dubei, O.; Ropyak, L.; Shovkoplias, M.; Pryhorovska, T.; Lozynskyi, V. Strategy of Compatible Use of Jet and Plunger Pump with Chrome Parts in Oil Well. Energies 2022, 15, 83. https://doi.org/10.3390/en15010083

Academic Editor: Marcin

Kremieniewski

Received: 13 November 2021

Accepted: 21 December 2021

Published: 23 December 2021

Publisher's Note: MDPI stays neutral with regard to jurisdictional claims in published maps and institutional affiliations.

Copyright: (C) 2021 by the authors. Licensee MDPI, Basel, Switzerland. This article is an open access article distributed under the terms and conditions of the Creative Commons Attribution (CC BY) license (https:// creativecommons.org/licenses/by/ $4.0 /)$.

\begin{abstract}
During oil fields operation, gas is extracted along with oil. In this article it is suggested to use jet pumps for utilization of the associated oil gas, burning of which causes environmental degradation and poses a potential threat to the human body. In order to determine the possibility of simultaneous application of a sucker-rod pump, which is driven by a rocking machine, and a jet pump (ejector) in the oil well, it is necessary to estimate the distribution of pressure along the borehole from the bottomhole to the mouth for two cases: when the well is operated only be the sucker-rod pump and while additional installation of the oil-gas jet pump above its dynamic level. For this purpose, commonly known methods of Poettman-Carpenter and Baksendel were used. In addition, the equations of high-pressure and low-pressure oil-gas jet pumps were obtained for the case, when the working stream of the jet pump is a gas-oil production mixture and the injected stream is a gas from the annulus of the well. The values which are included in the resulting equations are interrelated and can only be found in a certain sequence. Therefore, a special methodology has been developed for the practical usage of these equations in order to calculate the working parameters of a jet pump based on the given independent working parameters of the oil well. Using this methodology, which was implemented in computer programs, many operating parameters were calculated both for the well and for the jet pump itself (pressures, densities of working, injected and mixed flows, flow velocities and other parameters in control sections). According to the results of calculations, graphs were built that indicate a number of regularities during the oil well operation with such a jet pump. The main result of the performed research is a recommendation list on the choice of the oil-gas jet pump location inside the selected oil well and generalization of the principles for choosing the perfect location of such ejectors for other wells. The novelty of the proposed study lays in a systematic approach to rod pump and our patented ejector pump operation in the oil and chrome plating of pump parts. The result of scientific research is a sound method of determining the rational location of the ejector in the oil well and the calculation of its geometry, which will provide a complete selection of petroleum gas released into the annulus of the oil well. To ensure reliable operation of jet and plunger pumps in oil wells, it is proposed to use reinforcement of parts (bushings, plungers, rods, etc.) by electrochemical chromium plating in a flowing electrolyte. This has significantly increased the wear resistance and corrosion resistance of the operational surfaces of these parts and, accordingly, the service life of the pumps. Such measures will contribute to oil production intensification from wells and improve the environmental condition of oil fields.
\end{abstract}

Keywords: jet pump; oil; well; sucker-rod pump; gas-water-oil mixture; chrome coating 


\section{Introduction}

It is almost impossible to avoid associated gases extraction during the operation of oil field. These associated gases consist of gas mixture, which contains methane and propanebutane fraction. It requires separation into fractions in special gas processing plants, which are not always present near oil producing areas. Therefore, in oil fields these gases are often burnt in flares and the products of their combustion are a potential threat to the human body.

The practice of associated oil gas utilization using flare units is very dangerous for the environment [1]. For each ton of extracted oil there is from $25 \mathrm{~m}^{3}$ to $800 \mathrm{~m}^{3}$ of associated gas [2]. During the combustion of oil gas, a large amount of mutagenic and toxic substances (carbon oxides, nitrogen oxides, sulfur dioxide, hydrocarbons, soot) are released into the environment, which, when they enter the living organism, lead to the development of irreversible changes caused by the bioaccumulation effect [3-5]. In particular, in the regions that are influenced by the combustion plants, the population is suffering from an increased disease incidence of circulatory, respiratory, digestive and endocrine systems. The effect from combination of several compounds is synergistically upset while the response from the influence of several pollutants is greater than the summation of separate effects [6-9].

Oil producing countries and companies have created a partnership association "Global Gas Flaring Reduction Partnership" GGFR. The purpose of this association is to reduce the environmental impact from gas combustion at flare units through the creation of an appropriate legislative framework and expansion of markets for the disposal of associated gases [10]. Additionally, the promising method of associated gas utilization is using jet pumps for its capturing. The potential energy of the associated oil gas, when properly used, can serve to raise the production fluid to the surface [11-14]. Due to the gas adding to the water-oil mixture of the well, it is possible to reduce the fluids density to such level that it will even reduce the minimum required outlet pressure of the sucker-rod pump, which is used for oil well operation $[15,16]$. The paper in [17] describes the fundamental possibility of joint operation of the ground jet pump in the conditions of sinusoidal change of the working flow and the rod pump.

A perspective solution for the creation of a gas-water-oil mixture inside the well is inserting of a jet pump in it. Such jet pump, due to the flow of production fluid that will pass through it, will offtake free oil gas from the annulus, mix it with fluid and such mixture of a significantly lower density will be pumped to the mouth of the well. Jet pump can be installed either inside the tubing or in the annulus. With a correctly selected location for such an oil-gas jet pump in the well it will reduce the tubing load and decrease the electric energy consumption of the plunger pump. In addition, to ensure efficient operation of wells, it is necessary to increase the service life of pumps, as their replacement requires significant resources and leads to the cessation of oil production.

Analysis of the method of calculating the pressure distribution in the well, as well as its improvement proposed to clarify the results by the methods of Poettman-Carpenter and Baksendel was given by the authors in the previously published article [18].

\subsection{State of the Current Development of the Problem and Formulating a Research Task}

Oil and gas equipment, plunger, centrifugal and jet pumps are operated in extreme conditions during oil production. They are subject to high alternating loads in aggressive environments with the content of solid abrasive particles of rock at elevated temperatures [19]. The action of these factors leads to intensive corrosion and mechanical wear and destruction of machine parts, so the design, materials for their manufacture and technologies for strengthening parts are subject to increased requirements. Jet pumps are widely spread in different areas of modern technology. In recent decades, they have been used directly in oil production. For many cases, during oil wells operation with electrical submersible pump (ESP), additional jet pump usage ensured the stabilization of the ESP work. At the same time, this allowed to use the energy of free petroleum gas, which is 
always present in the injected flow and, to a certain extent, this provides an increase in the well's flow rate [20]. In this case the jet pump was installed directly above the ESP.

To create reliable and efficient jet pumps for oil production, it is necessary to develop a theory of their operation. Theoretical issues related to the operation of jet pumps in oil wells were considered in the works in [21,22]. Practical issues related to the efficiency and reliability of pumping equipment are considered in [23-25]. A case of placing the jet pump above the dynamic level of the well is also used in order to extract gas from its annulus, which made it possible to stabilize the dynamic level and increase the reliability of the ESP system [26]. In this case, the injected flow of the jet pump is oil gas, which is accumulated in the annulus.

After this technology showed its effectiveness, such oil-gas jet pumps were proposed to be used together with sucker-rod pumps [27] or individually in complicated production conditions [28,29]. It should be noted here that a sucker rod string could be subjected to abnormal static and dynamic loads [30-32] especially for complex profile wells. Some authors [33-35] consider vibration reduction of oil equipment as a guarantee of dynamic stability of pump rod strings and ensuring the stability of submersible pumps. Actual problems of anti-vibration device designing for long structures (rod strings, pipe strings, etc.) were considered in [36-38], recommendations for over-loaded pump reliability are given in [39-41].

The high profitability of oil-gas jet pumps was also proven in case of their application for gas-lifting operation of wells [42-44]. In general, jet pumps can improve the operation of the equipment they work with, extend its overhaul period and increase oil recovery. Due to such a list of advantages, jet pumps are installed in different places inside of oil wells (near the bottomhole, above and below the dynamic level, on the surface and near the mouth) [45].

A technique for selection of the geometrical parameters for the downhole ejection system's body with an external placement of several jet pumps is presented [46]. To assess the strength of the jet pump's bodies, the theory of membrane-free shells with via openings or cutouts is used $[47,48]$. The presence of technological openings, designed to attach jet pumps, contributes to the uneven distribution of stresses and, as a result, reduce the fatigue life of such structures. The problems of stress concentration in shell systems under conditions of contact interaction while complex loading were considered in [49-51]. When designing such equipment, engineers pay special attention to the accuracy and tightness of threaded joints [52-54], increasing thread [55-57] and preventing self-unscrewing of threaded joints $[58,59]$.

Concerning the features of the design of modern ejection systems that are operated under aggressive conditions, some authors suggest the use metallic ceramics or ceramic coatings to provide the required operational life of the nozzle [60-62]. Recommendations have been made on the technology of forming, optimal design and calculation of the operational properties of single layer $[63,64]$, flexible $[65,66]$ or multilayer ceramic coatings [67-69]. Thermoplastic composite materials are also widely used [70-73]. For surface hardening of parts of elite models of downhole ejection systems, chromium plating in a flowing electrolyte is used, as well as functionally gradient coatings of required parts of surfaces [74-76]. New technological schemes for hydrocarbon development from used wells to use additionally non-commercial and closed deposits and extend mining enterprise operation are presented in [77-80].

Therefore, one of the most important tasks before the implementation of jet pump technologies in production was the development of a methodology for calculating their working and geometric parameters, as well as technologies to strengthen their parts. Literature review, analyses of patents and regulations on electrochemical chromium plating of parts in quiet and flowing electrolytes showed that chromium plating in quiet electrolyte does not provide a uniform thickness of coatings, and the formation of coatings in flowing electrolyte occurs at higher current densities [62]. This ensures uniform application of the coating layer with low roughness, as well as achieving high coating performance 
and increased current yield of chromium. Increasing the service life of pumps can be achieved through the use of reinforcing technologies in the manufacture of their parts by chrome plating.

The issues of obtaining theoretical dependences and their usage for practical calculations of jet pumps are described in [81]. Since the theory of jet devices, installed above the dynamic level of oil wells, which are operated by sucker-rod pumps, has already been developed [82], it is possible to proceed directly to determining the rational location of such jet pumps in wells and calculating their geometry with strengthening of their details.

\subsection{Purpose and Tasks of Research}

Thus, the purpose of this article is to determine such location of the oil-gas jet pump inside of the oil well, which will provide the maximum possible reduction of outlet pressure for the sucker-rod pump and decrease the tubing load; as well as being used in development of technology of strengthening of details of jet and plunger pumps by chrome coverings. The formulated purpose can be achieved by solving the following tasks:

- calculating the distribution of operating parameters along the borehole of the oil well, operated by a sucker-rod pump;

- performing the calculation of geometric and thermobaric parameters of oil-gas jet pumps, installed at different depths in the oil well;

- analyzing which of the considered operation modes is the most profitable and determine which variables have the strongest affect on the efficiency of jet pumps' usage in the oil well;

- calculating the technologically possible reduction of the outlet pressure for the suckerrod pump and tubing load for optimal operation mode;

- developing a technology of electrochemical chromium plating in the flow electrolyte of the working surfaces of the parts of jet and plunger pumps.

\section{Materials and Methods}

\subsection{Features of Design, Manufacture and Strengthening by Chrome Plating of Details of Pumps}

To strengthen the parts of jet and plunger pumps, an installation for electrochemical chromium plating in a flowing electrolyte and a technological process of coating the parts of these pumps were developed. The installation for electrochemical chrome plating of pump parts in a flowing electrolyte contains interchangeable electrochemical cells used for coating the outer surfaces of the plunger or rod, respectively, or the inner surfaces of the plunger pump sleeve and the jet pump ejector. The electrochemical cell, after mounting the part and the electrode in it, was sealed and connected by means of current leads to the power supply, and by pipes-to the system of electrolyte supply to the annular cavity between the electrodes of the cell. The unit is equipped with an automated control system for electrochemical chromium plating in the flow electrolyte, which allows to maintain independently at a given level the technological parameters of electrolysis: temperature, electrolyte flow rate, electrolysis operating current and the ratio of electrolyte components. Chrome coatings were applied to the working surfaces of pump parts made of steel 40KHN (GOST 4543-2016), which were surface hardened with high frequency currents and subjected to grinding. The anode was an alloy of lead with sulfur and tin. Chrome plating of pump parts (ejectors, bushings, plungers, rods) was performed in a standard electrolyte based on chromic anhydride and sulfuric acid with nano-additives.

To reduce the harmful effects of chromium electrolyte on the environment during the application of electrochemical chrome coating on the pump parts the developed design of the electrochemical sealed cell was used. The system for supplying electrolyte to the annular cavity formed between the electrodes of the electrochemical sealed cell is equipped with a unit for neutralization and purification of gaseous electrolysis products according to our invention [83]. The amount of harmful emissions released into the atmosphere does not exceed the maximum allowable concentration. 


\subsection{Determination of Rational Placement of the Jet Pump in the Well}

Instead of directing the extracted gas from the well space directly to the flare for its combustion, the article proposes mixing oil gas with well products in the downhole ejector, which allows to use its potential energy of this gas. In the future, this gas is separated at oil treatment plants, and then it can be sent for further use or for the needs of production, or for the current needs of maintenance personnel. The innovation proposed in the article eliminates the combustion of emitted gas during the operation of oil wells, which reduces the amount of emissions of carbon dioxide and other combustion products into the atmosphere. Such measures improve the environmental situation in the oil and gas fields.

In order to determine the rational placement of the oil-gas jet pump in the oil well 753-D Dolyna Oil Field "Dolynanaftogaz" PJSC "Ukrnafta”, first of all, it is necessary to calculate the distribution of thermobaric and other operating parameters along its borehole and also to find the daily amount of oil gas, entering its annulus [18].

The scheme of the general layout and the mutual placement of the sucker-rod pump and the oil-gas jet pump is shown in Figure 1 [84].

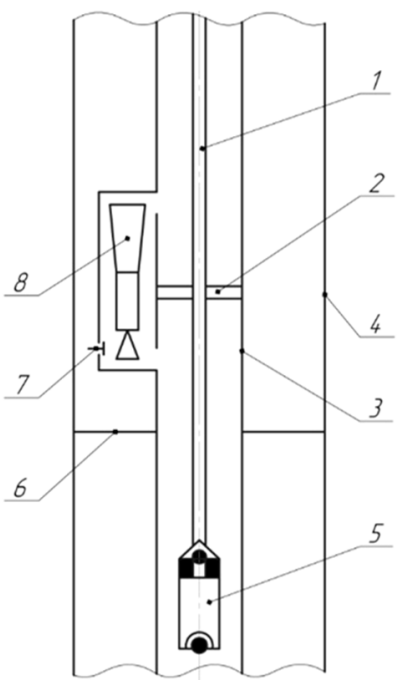

Figure 1. General layout of the tandem installation [84]: 1-rods; 2-separator; 3-tubing string; 4-casing; 5-sucker-rod pump; 6-dynamic level; 7—check valve; 8—oil-gas jet pump.

The wellbore fluid, which is pumped by the sucker-rod pump (5) into the tubing string (3), enters the oil-gas jet pump (8), which is placed in the annulus, where, due to its high velocity, the associated gas from the annular space enters the ejector through the return valve (7). Then this gas-liquid mixture returns back to the tubing and then moves to the mouth of the well. Inside the tubing at the jet pump's level, a separator (2) must be installed to ensure that the ejector's input and output are not connected. More detailed view of the suggested design for the oil-gas jet pump is shown in Figure 2. 


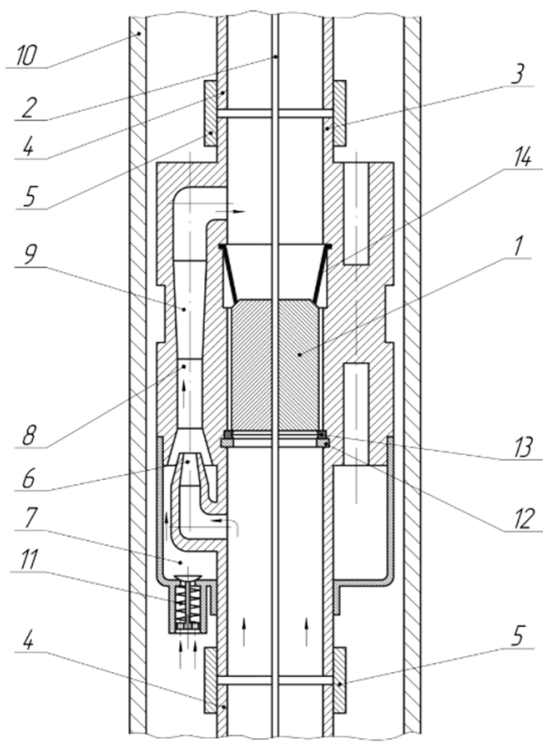

Figure 2. Construction scheme of the downhole oil-gas jet pump [85]: 1—separator; 2-rod; 3-jet pump's body; 4-tubing; 5-collar; 6-working nozzle; 7-receiving chamber; 8-mixing chamber; 9-diffuser; 10-casing; 11—check valve; 12-spring ring; 13-packing seal; 14-retainer.

In order to determine the location of the jet pump inside the oil well, first of all the range of possible depths of the jet pump placement was selected: from $610 \mathrm{~m}$ to $890 \mathrm{~m}$. Low-pressure jet pumps with a ratio of the mixing chamber and the nozzle cross-section areas equal to 6.25. With the help of a created computer program, the outlet pressure for the jet pump was found, as well as a number of its variable parameters (like geometric dimensions), based on the improved Poettman-Carpenter method, which is used for calculation of thermobaric parameters' distribution in wells. In such case, the working flow for the jet pump will be the gas-oil mixture of the well and the injected flow-oil gas from the annulus.

The study [18] considered in details all the values included in the Poettman-Carpenter and Baxendel equation and explains the procedure for implementing this calculation. The scientific novelty of the proposed methods is to solve nonlinear differential equations on which the Poettman-Carpenter and Baxendel methods are based, the Adams-Krylov numerical method, which excludes a number of assumptions made in the original methods (including assumptions about the linear relationship between temperature and pressure). wells). Comparison of the results of the proposed and well-known methods is presented in [86].

The phenomenon of cavitation and ejector efficiency have not been studied by the authors. The work [87] is devoted to obtaining the characteristics of high-pressure and low-pressure ejectors operating in an oil well; this article also presents the curves of characteristics of these jet pumps to represent dependences of dimensionless relative difference of pressure on coefficient of injection are resulted.

As input parameters in this program we have taken: pressure of the working flow before entering the jet pump, its density, consumption gas content, the density of free gas. All of these parameters were equal to the correspondent parameters of considered oil well. In addition, the velocity of the working flow before the nozzle is also known as far as it was previously determined through the average integral velocity of the production liquid in the tubing. Finally, we have values of pressure in the receiving chamber of the jet pump, the finding of which was described in article [61].

The basic parameter of any jet pump, which influences all the rest geometric and working parameters of it, is the cross-section area of the working nozzle. In the course of 
mathematical transformations, a formula for determining cross-section area of the nozzle was obtained [84]:

$$
f_{1}=w_{w} f_{w}\left[\left(1-\beta_{w}\right) p_{1}+\beta_{w} p_{w}\right] \sqrt{\frac{\left(1+\xi_{n}\right) \rho_{w}}{\left[2 p_{w}\left(1-\beta_{w}\right)+\rho_{w} w_{w}^{2}\right] p_{1}^{2}-2\left(1-\beta_{w}\right) p_{1}^{3}}}
$$

where $w_{w}$ is velocity of the working liquid before entering the nozzle, $\mathrm{m} / \mathrm{s} ; f_{w}$ is crosssection area in the outlet of a nozzle, $\mathrm{m}^{2} ; \beta_{w}$ is consumption gas content under working conditions of a well; $p_{1}$ is pressure of the working liquid at the outlet of a nozzle, $\mathrm{Pa} ; p_{w}$ is pressure of the working liquid before entering the nozzle, $\mathrm{Pa} ; \xi_{n}$ is resistance coefficient of the nozzle; $\rho_{w}$ is density of the working liquid before entering the nozzle, $\mathrm{kg} / \mathrm{m}^{3}$.

Based on the found area of the nozzle, the cross-section area of the mixing chamber was calculated $\left(f_{3}=6.25 f_{1}\right)$ and the diameters of the nozzle $d_{n}$ and the mixing chamber $d_{m c}$. The cross-section area in the outlet of the diffuser and its diameter were obtained from the condition that the angle of the diffuser's cone is $\alpha=8^{\circ}$ and the length of the diffuser is equal to the twelve diameters of the mixing chamber.

First, the Bernoulli equations for the working flow within the nozzle, the receiving chamber and the mixed flow for the diffuser, as well as the equation of change of the amount of motion (pulse conservation) for the working and injected flows in the cylindrical mixing chamber are recorded. In the last equation, all flow rates are expressed in terms of volume costs. From Bernoulli's equations are expressed the pressures at the inlet and outlet of the mixing chamber and substitute in the equation of change in the amount of motion. We express the terms in the right part of the obtained equation, which contain the flow velocities in different sections of the ejector due to the flow of working and injected flows at the entrance to the mixing chamber. The law of conservation of mass is written down and substituted into the previously obtained equation (the product of the cross section at the entrance to the mixing chamber at the expense of the workflow). As a result, we obtain the equation of the oil and gas ejector. This derivation is given in more detail in [84,87].

The variable parameters of the jet pump were determined in a certain sequence and as a result of solving characteristic equations for jet pumps [58] and to find the outlet pressure the equation of a low-pressure oil-gas jet pump was used:

$$
\begin{gathered}
\frac{2 f_{1}^{2} \rho_{1}^{2}}{\left(1+\xi_{n}\right) \rho_{w} f_{3}}\left(p_{w}-p_{1} \frac{\rho_{w}}{\rho_{1}}+\frac{\rho_{w} w_{w}^{2}}{2}\right) \times\left\{\frac{1}{f_{1} \rho_{1}}+\frac{\rho_{i n 2}}{\rho_{1}^{2} f_{i n 2}} u_{2}^{2}\left[1-\frac{k-1}{2 k}\left(1+\xi_{i n}\right)\right]-\right. \\
\left.-\left(\xi_{d}+\xi_{m c}+1\right) \frac{1}{2 f_{3} \rho_{3}}\left(1+\frac{\rho_{i n 2}}{\rho_{1}} u_{2}\right)^{2}\right\}-p_{m} \frac{\rho_{3}}{\rho_{m}}-\frac{\rho_{3} w_{m}^{2}}{2}+p_{1} \times \\
\times\left[1-\left(1-\frac{\rho_{i n 2}}{\rho_{i n}}\right) \frac{f_{i n 2}}{f_{3}}\right]+\frac{k-1}{2 k} \frac{f_{i n 2}}{f_{3}} \rho_{i n 2} w_{i n}^{2}=0,
\end{gathered}
$$

where $f_{1}$ is cross-section area in the outlet of a nozzle, $\mathrm{m}^{2} ; \rho_{1}$ is density of the working liquid at the outlet of a nozzle, $\mathrm{kg} / \mathrm{m}^{3} ; f_{3}$ is cross-section area at the outlet of a mixing chamber, $\mathrm{m}^{2} ; \rho_{i n 2}$ is density of the injected gas before entering the mixing chamber, $\mathrm{kg} / \mathrm{m}^{3}$; $f_{i n 2}$ is cross-section area of the injected gas before entering the mixing chamber, $\mathrm{m}^{2} ; u^{2}$ is injection ratio before entering the mixing chamber; $k$ is adiabatic exponent; $\xi_{i n}, \xi_{m c}, \xi_{d}$ are resistance coefficients for the inlet of injected gas to the mixing chamber, in the mixing chamber and diffuser; $\rho_{3}$ is density of the mixed flow at the outlet of the mixing chamber, $\mathrm{kg} / \mathrm{m}^{3} ; \rho_{m}$ is density of the mixed flow at the outlet of the diffuser, $\mathrm{kg} / \mathrm{m}^{3} ; p_{m}$ is pressure of the mixed flow at the outlet of the diffuser, $\mathrm{Pa} ; w_{m}$ is velocity of the mixed flow at the outlet of the diffuser, $\mathrm{m} / \mathrm{s} ; \rho_{\text {in }}$ is density of the injected gas while entering the mixing chamber, $\mathrm{kg} / \mathrm{m}^{3} ; w_{\text {in }}$ is velocity of the injected gas while entering the mixing chamber, $\mathrm{m} / \mathrm{s}$.

Equation (2) was obtained based on Bernoulli equation and mass conservation law. It can be used for jet pumps, where the working and mixed flows are compressible two-phase liquids [84]. 
In order to establish the pressure distribution between the jet pump and the mouth based on the known parameters of the mixed flow after the jet pump, a computer program was created, where the Baksendel method was applied [61].

After building up the pressure distribution curves along the wellbore, taking into account the presence of the jet pump, it is necessary to analyze the obtained value of the wellhead pressure. If the wellhead pressure is higher than technologically required, that means that it is allowed to reduce the pressure in every point of the wellbore starting from the outlet of the sucker-rod pump as long as the form of the curve remains the same. However, if the wellhead pressure turned to be lower than technologically required it is essential to consider other installation depth of even another jet pump (means with other geometrical parameters).

In addition to low-pressure jet pumps, which are able to prove high flow rates of liquid and gas but with a great pressure drop in the jet pump, there are high-pressure jet pumps with cross-section areas ratio $f_{3} / f_{1}=3$ and less. These jet pumps have smaller pressure losses but can inhaust less gas.

The methodology of choosing the rational place of such jet pumps in oil well is exactly the same as for the low-pressure jet pumps. The only difference is in the characteristic equation for finding outlet pressure of jet pump:

$$
\begin{aligned}
& \frac{2 f_{1}^{2} \rho_{1}^{2}}{\left(1+\tilde{\zeta}_{n}\right) \rho_{w 1} f_{3}}\left(p_{w}-p_{1} \frac{\rho_{w}}{\rho_{1}}+\frac{\rho_{w w} w_{w}^{2}}{2}\right) \times\left[\frac{1}{f_{w 2} \rho_{w 2}}+\frac{\rho_{i n 2}}{\rho_{w 2}^{2} f_{i n 2}} u_{2}^{2}-\right. \\
& \left.-\frac{1}{2}\left(1+\frac{\rho_{i n 2}}{\rho_{w 2}} u_{2}\right)^{2}\left(\frac{\xi_{d}+\xi_{m c}+1}{f_{3} \rho_{3}}+\frac{f_{3} \rho_{3}}{f_{m}^{2} \rho_{m}^{2}}\right)\right]-p_{m} \frac{\rho_{3}}{\rho_{m}}+p_{2}=0,
\end{aligned}
$$

where $f_{w 2}$ is cross-section area of the working liquid before entering the mixing chamber, $\mathrm{m}^{2} ; \rho_{w 2}$ is density of the working liquid before entering the mixing chamber, $\mathrm{kg} / \mathrm{m}^{3} ; p_{2}$ is pressure of the working liquid before entering the mixing chamber, $\mathrm{Pa}$.

\section{Results}

Table 1 shows some of the results obtained using mentioned programs for low-pressure oil-gas jet pumps.

As can be seen from the Table 1 , if the inlet parameters of the jet pump ( $\left.p_{w}, \rho_{w}, \beta_{w}, w_{w}\right)$ in the cross-section of the well where it is installed were the same as in the well without jet pump, then the pressure at the wellhead would be less than necessary (should be $0.5 \mathrm{MPa}$ ). The only exception is the jet pump installed at a depth of $890 \mathrm{~m}$. This jet pump will provide a slightly higher wellhead pressure $\left(p_{w h}=0.52 \mathrm{MPa}\right)$.

As soon as the pressure at the wellhead should be $p_{w h}=0.5 \mathrm{MPa}$, that requires installation depth of jet pump not less than $890 \mathrm{~m}$.

What is then the cause of this phenomenon? After all, the relation between the flow densities at the inlet and at the outlet of the jet pump it is quite significant $\left(p_{w} / p_{m}=2.06-2.246\right)$. In addition, outlet pressure of the jet pump is significantly less than the inlet pressure, which leads to a substantial flash gas liberation. Yet, despite this, during the movement of production liquid to the mouth, the pressure is dropping faster in case of jet pump installation compared to the option without it.

Figure 3 shows the pressure distribution between jet pumps, placed in different depth, and the wellhead for the case when the inlet pressure of jet pumps would be equal to the pressure in the corresponding cross-sections of the well before jet pumps installation (curves 2, 3, 4 and 5). 
Table 1. Input and calculated parameters of the oil well and the jet pump when it is installed at different depths.

\begin{tabular}{|c|c|c|c|c|c|c|}
\hline \multirow{2}{*}{ Parameters } & \multicolumn{6}{|c|}{ Depth of Jet Pump Installation, m } \\
\hline & 610 & 650 & 700 & 800 & 850 & 890 \\
\hline \multicolumn{7}{|c|}{ Input parameters } \\
\hline Pressure at the inlet of jet pump $p_{w},(\mathrm{MPa})$ & 3.21 & 3.51 & 3.91 & 4.75 & 5.20 & 5.56 \\
\hline Density of working liquid $\rho_{w},\left(\mathrm{~kg} / \mathrm{m}^{3}\right)$ & 724.7 & 763.1 & 806.4 & 876.7 & 904.0 & 922.5 \\
\hline Consumption gas content $\beta_{w}$ & 0.208 & 0.169 & 0.125 & 0.052 & 0.024 & 0.004 \\
\hline $\begin{array}{l}\text { Velocity of the working liquid before } \\
\text { entering the nozzle } w_{w},(\mathrm{~m} / \mathrm{s})\end{array}$ & 3.3 & 3.1 & 2.9 & 2.7 & 2.6 & 2.6 \\
\hline Density of free gas $\rho_{g},\left(\mathrm{~kg} / \mathrm{m}^{3}\right)$ & 26.4 & 29.1 & 32,5 & 40.1 & 44.2 & 47.5 \\
\hline \multicolumn{7}{|c|}{ Calculated parameters } \\
\hline Diameter of the nozzle $d_{n},(\mathrm{~mm})$ & 4.3 & 4.0 & 3.7 & 3.1 & 2.9 & 2.8 \\
\hline Diameter of the mixing chamber $d_{m c},(\mathrm{~mm})$ & 10.7 & 9.9 & 9.1 & 7.8 & 7.3 & 6.9 \\
\hline Outlet diameter of the diffuser $d_{d},(\mathrm{~mm})$ & 28.6 & 26.6 & 24.4 & 21.0 & 19.6 & 18.6 \\
\hline $\begin{array}{l}\text { Density of the mixed flow at the outlet of the } \\
\text { jet pump } \rho_{m},\left(\mathrm{~kg} / \mathrm{m}^{3}\right)\end{array}$ & 324.4 & 339.7 & 360.2 & 404.6 & 428.1 & 447.4 \\
\hline $\begin{array}{l}\text { Pressure of the mixed flow at the outlet of } \\
\text { the jet pump } p_{m},(\mathrm{MPa})\end{array}$ & 2.12 & 2.20 & 2.31 & 2.58 & 2.73 & 2.87 \\
\hline Wellhead pressure $p_{\text {wh }},(\mathrm{MPa})$ & 0.47 & 0.42 & 0.39 & 0.42 & 0.47 & 0.52 \\
\hline $\begin{array}{l}\text { Density of the mixed flow at the wellhead } \\
\rho_{m}{ }^{(w h)},\left(\mathrm{kg} / \mathrm{m}^{3}\right)\end{array}$ & 33.8 & 30.6 & 28.3 & 30.0 & 33.9 & 37.9 \\
\hline
\end{tabular}

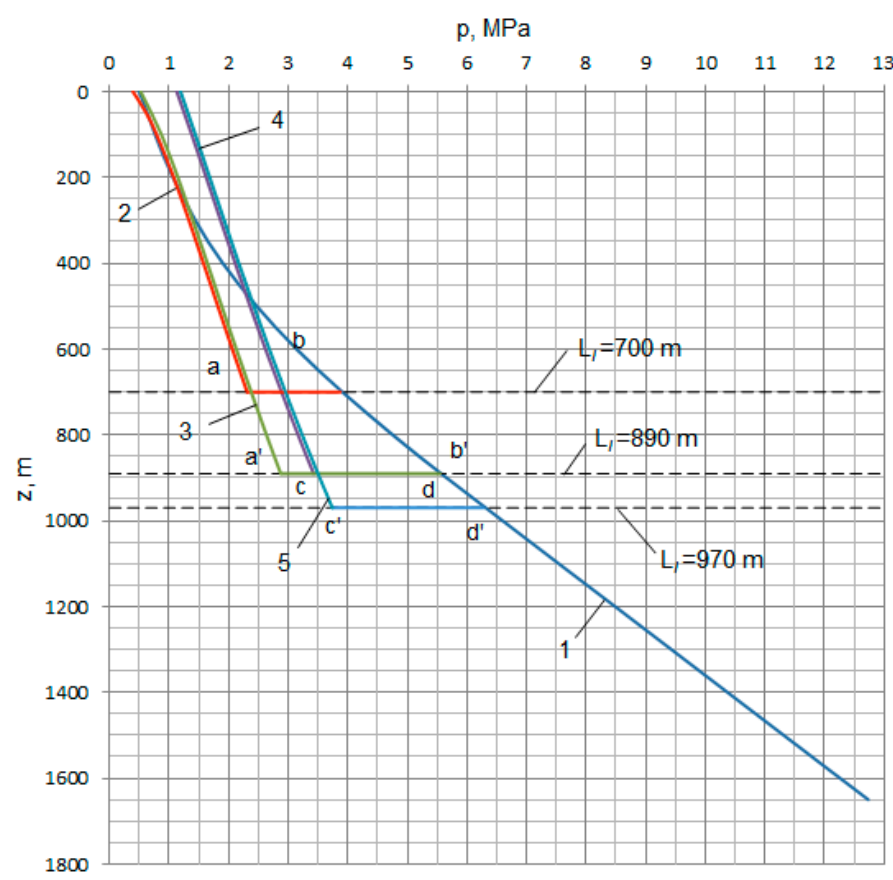

Figure 3. Pressure distribution along the wellbore between jet pumps and wellhead: 1 -wellbore pressure distribution; 2, 3-pressure distribution after using jet pump with $f_{3} / f_{1}=6.25 ; 4,5$-pressure distribution after using jet pump with $f_{3} / f_{1}=4$.

Curves 2 and 3 correspond to jet pumps with the cross-sections ratio $f_{3} / f_{1}=6.25$ and curves 4 and 5 correspond to jet pumps with the cross-sections ratio $f_{3} / f_{1}=4$. In addition, the pressure distribution in oil well between the sucker-rod pump and the wellhead (curve 1) without using jet pump is additionally depicted. The pressure in all four cases decreases almost linearly and much more slowly than in the well without jet pump. The only exception is for the part of the wellbore (approximately $200 \mathrm{~m}$ ) straight below the mouth, where the pressure drop with and without jet pump is almost the same.

A smaller pressure change gradient is caused by the presence of a significant amount of free gas from the annulus in the tubing. The actual constancy of the pressure change 
gradient can be explained by the fact that, on the one hand, an increase in the amount of gas in the production liquid should cause a decrease in the pressure change gradient, and, on the other hand, as the amount of gas in the mixture increases, its velocity also increases and this causes the growth in friction losses. These two variable losses almost compensate each other.

The reason for the small wellhead pressure, which low-pressure jet pumps with crosssection areas ratio $f_{3} / f_{1}=6.25$ can provide, when the depth of their placement in the well changes in the range from $610 \mathrm{~m}$ to $890 \mathrm{~m}$, is a significant pressure drop between inlet and outlet of the jet pump. In Figure 3, these pressure drops are represented by the segments $a b$ and $a^{\prime} b^{\prime}$. Jet pumps with cross-section areas ratio $f_{3} / f_{1}=4$, as it can be seen from Figure 3 , allow to obtain significantly greater wellhead pressure than the previous two.

If these jet pumps are installed in the oil well 753-D, then placing the jet pump at a depth of $700 \mathrm{~m}\left(f_{3} / f_{1}=6.25\right)$ will entail a slight increase in inlet pressure compared to the pressure in this cross-section of the well without a jet pump. At the same time, the jet pump, located at a depth of $890 \mathrm{~m}\left(f_{3} / f_{1}=6.25\right)$, on the contrary, will give a slight decrease in inlet pressure compared to the pressure in this cross-section of the well without a jet pump. Jet pumps with cross-section areas ratio $f_{3} / f_{1}=4$ will provide a noticeable decrease in pressure in front of the jet pump, and, consequently, a substantial decrease in outlet pressure of the sucker-rod pump.

Thus, it follows from the above that an increase of the installation depth for such jet pumps will have a little affect on the pressure change in front of it. With increasing of jet pump placement depth in the well, the inlet pressure of it will slightly reduce. It turned out that even greater influence on inlet pressure decreasing has the cross-section areas ratio $f_{3} / f_{1}$.

It would be possible to determine to which level low-pressure jet pumps with the ratio $f_{3} / f_{1}=4$ can reduce the outlet pressure of the sucker rod pump. However, since we have proven that the inlet pressure of the jet pump substantially depends on the value $f_{3} / f_{1}$, it is necessary to consider installation of high-pressure jet pumps, for which the value of cross-section areas ratio is $f_{3} / f_{1}<4$. Such jet pumps provide the highest possible pressure at their outlet.

Table 2 shows the input and some calculated values for such jet pumps, taking into account that input parameters in this case are equal to the corresponding parameters of the well at depths of 700, 800, 850 and $870 \mathrm{~m}$.

Table 2. Input and calculated parameters of the high-pressure oil-gas jet pumps during their installation in oil well at different depths [84].

\begin{tabular}{|c|c|c|c|c|}
\hline \multirow{2}{*}{ Parameters } & \multicolumn{4}{|c|}{ Depth of Jet Pump Installation, $\mathrm{m}$} \\
\hline & 700 & 800 & 850 & 870 \\
\hline \multicolumn{5}{|c|}{ Input parameters } \\
\hline Pressure at the inlet of jet pump $p_{w},(\mathrm{MPa})$ & 3.91 & 4.75 & 5.20 & 5.38 \\
\hline Density of working liquid $\rho_{w},\left(\mathrm{~kg} / \mathrm{m}^{3}\right)$ & 806.4 & 876.7 & 904.0 & 913.6 \\
\hline Consumption gas content $\beta_{w}$ & 0.125 & 0.052 & 0.024 & 0.014 \\
\hline Density of free gas $\rho_{g},\left(\mathrm{~kg} / \mathrm{m}^{3}\right)$ & 32.5 & 40.1 & 44.2 & 45.8 \\
\hline $\begin{array}{l}\text { Velocity of the working liquid before } \\
\text { entering the nozzle } w_{w},(\mathrm{~m} / \mathrm{s})\end{array}$ & 2.9 & 2.7 & 2.6 & 2.6 \\
\hline \multicolumn{5}{|c|}{ Calculated parameters } \\
\hline $\begin{array}{l}\text { Density of the mixed flow at the outlet of } \\
\text { the jet pump } \rho_{m},\left(\mathrm{~kg} / \mathrm{m}^{3}\right)\end{array}$ & 418.7 & 485.9 & 523.6 & 541.9 \\
\hline $\begin{array}{l}\text { pressure of the mixed flow at the outlet of } \\
\text { the jet pump } p_{m},(\mathrm{MPa})\end{array}$ & 2.99 & 3.64 & 4.09 & 4.34 \\
\hline $\begin{array}{l}\text { Injection ratio before entering the mixing } \\
\text { chamber } u_{2}\end{array}$ & 1.36 & 1.57 & 1.69 & 1.74 \\
\hline $\begin{array}{l}\text { Velocity of the working liquid before } \\
\text { outflowing from the nozzle } w_{w},(\mathrm{~m} / \mathrm{s})\end{array}$ & 64.9 & 76.6 & 82.1 & 84.2 \\
\hline
\end{tabular}


After that, for these four jet pumps, the pressure distribution between them and the wellhead was determined using previously mentioned computer program for the Baksendel method. In Figures 4 and 5 the dotted line (curves 2) shows the pressure distribution between the jet pump, installed at depths of 700 and $870 \mathrm{~m}$ in the well, and its mouth, obtained from the results of this program.

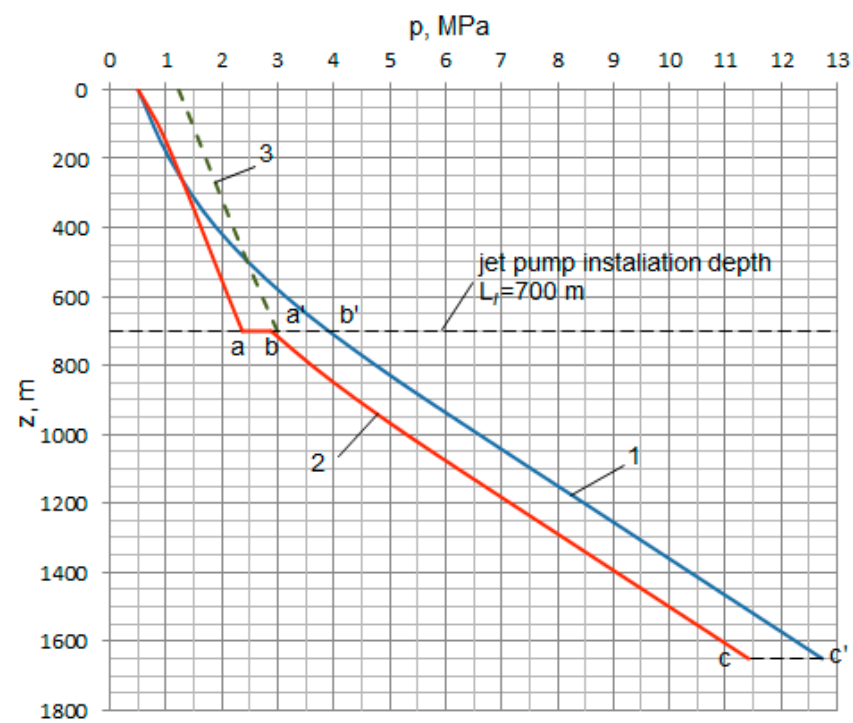

Figure 4. Pressure distribution between the sucker-rod pump and the wellhead: 1 -without the jet pump; 2 -with the jet pump $\left(f_{3} / f_{1}=3\right)$; 3-with the jet pump after decreasing inlet pressure $p_{w}=3.908 \mathrm{MPa}$.

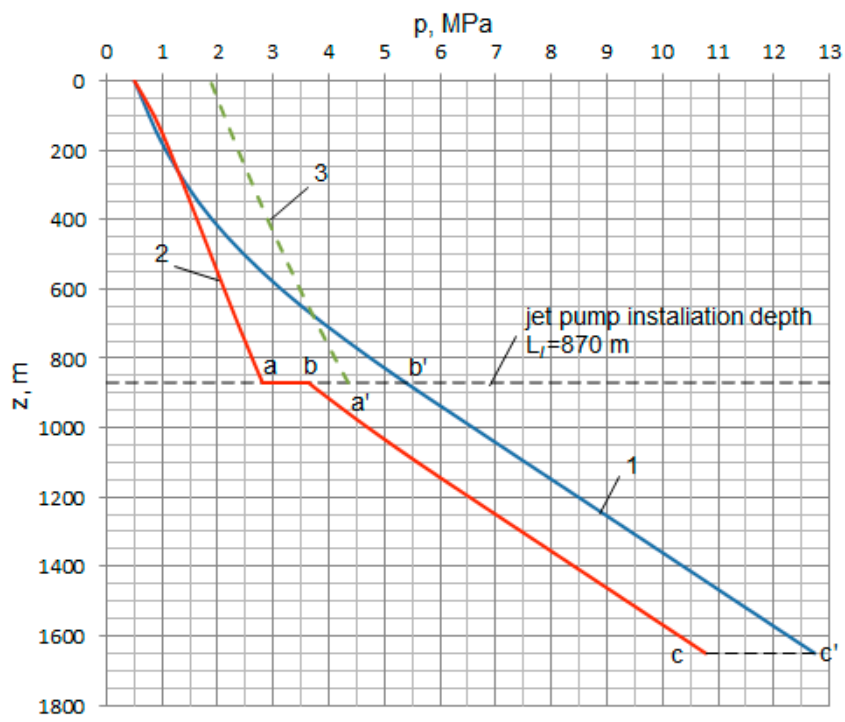

Figure 5. Pressure distribution between the sucker-rod pump and the wellhead: 1-without the jet pump; 2 -with the jet pump $\left(f_{3} / f_{1}=3\right)$; 3-with the jet pump after decreasing inlet pressure $p_{w}=5.381 \mathrm{MPa}$.

As seen in Figures 4 and 5, if the inlet pressure of the jet pump is equal to the pressure that exists in the well in this cross-section (in the figures it is point $b^{\prime}$ ), then the pressure at the wellhead will be greater than required $p_{w h}=0.5 \mathrm{MPa}$. Therefore, the next task was to find such inlet pressure of the jet pump, at which the wellhead pressure would be $0.5 \mathrm{MPa}$. The geometry and all other parameters of the jet pump were determined when its inlet pressure was changing, as well as the pressure distribution along the wellbore from the jet pump to the wellhead. 
By successively reducing the inlet pressure of the jet pumps, such values of it were found at which the wellhead pressure are equal to $0.5 \mathrm{MPa}$. Knowing the inlet pressure of the jet pumps and the temperatures at their installation points, calculations were made to determine the pressure distribution along the wellbore from jet pumps to the sucker-rod pump. According to the results of using created computer programs, pressure distribution curves for the oil well 753-D were built for cases of jet pumps installation at depths of 700 and $870 \mathrm{~m}$ respectively (curves 3 ) (Figures 4 and 5).

Figures 4 and 5 show that the usage of high-pressure jet pumps in the well can significantly reduce the outlet pressure of the sucker-rod pump. This reduction is from 1.32 MPa, for the case of jet pump installing at a depth of $700 \mathrm{~m}$ and up to $1.96 \mathrm{MPa}$, when jet pump is installed at a depth of $870 \mathrm{~m}$. Reducing the outlet pressure of the sucker-rod pump means decreasing the stem load. For the case that is considered, such a reduction in load can reach up to $26 \%$ (with a decrease in outlet pressure of sucker-rod pump by $1.96 \mathrm{MPa}$ ). In addition, by reducing the load on the beam pumping unit's mechanism, smaller counterbalance can be used [84].

Thus, we may say that it is the most rational to install the high-pressure jet pump with $f_{3} / f_{1}=3$ at depth of $870 \mathrm{~m}$ in the oil well 753-D Dolyna Oil Field "Dolynanaftogaz" PJSC "Ukrnafta".

In the general case, it can be claimed that usage of tandem installation, which consists of the sucker-rod pump and oil-gas jet pump is advisable when the gas-oil ratio of the well is around $100 \mathrm{~m}^{3} / \mathrm{t}$ and higher. However, even then the efficiency of such tandem installation will be determined by many other factors.

It is proposed to use an electrochemical chrome coating formed in a flowing electrolyte to increase the wear and corrosion resistance of the polished rod of the rod pump unit.

The cost of applying the chrome coating on parts in a flowing electrolyte does not exceed the cost of applying a chrome coating on parts in a quiet electrolyte-the traditional way. It should be noted that the application of a thick layer of electrochemical chrome coating in the flowing electrolyte reduces the amount of allowance for diamond grinding of parts compared to the quiet electrolyte [88], which ultimately reduces the cost of manufacturing the suitable chrome parts that have high microhardness to our technology (Figure 6).

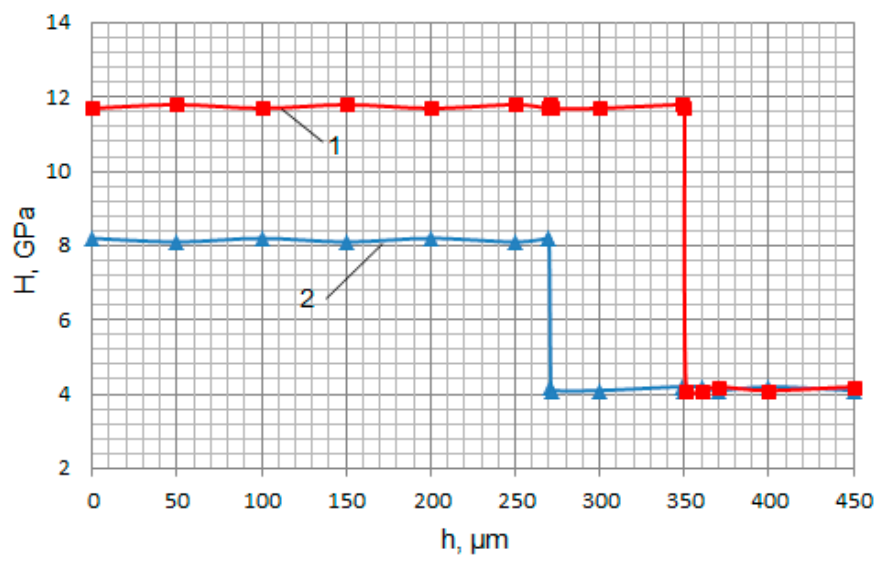

Figure 6. Change in microhardness according to the thickness of the chromium electrochemical coating formed in the electrolyte: 1 -flow; 2 -calm.

The use of chromium plating in a flowing electrolyte provides thicker coatings compared to chromium plating in a quiet electrolyte. In this case, the coatings applied in the flowing electrolyte evenly cover the steel base, have a lower surface roughness and higher microhardness (11.8 GPa) compared to chromium plating in the quiet electrolyte $(8.1 \mathrm{GPa})$. This is achieved by creating a stable flow of electrolyte in the annular interelectrode space of the electrochemical cell and intensive removal of gases formed during electrolysis on the 
surface of the part and the electrode. In addition, the saturation of the chrome coating and the steel base with hydrogen is reduced.

Tests of samples with chrome coatings were performed on an upgraded installation that simulates the reciprocating motion (reversible friction) of the polished rod of the rocking machine and allows you to continuously record the value of the coefficient of friction. The results are presented in Figure 7.

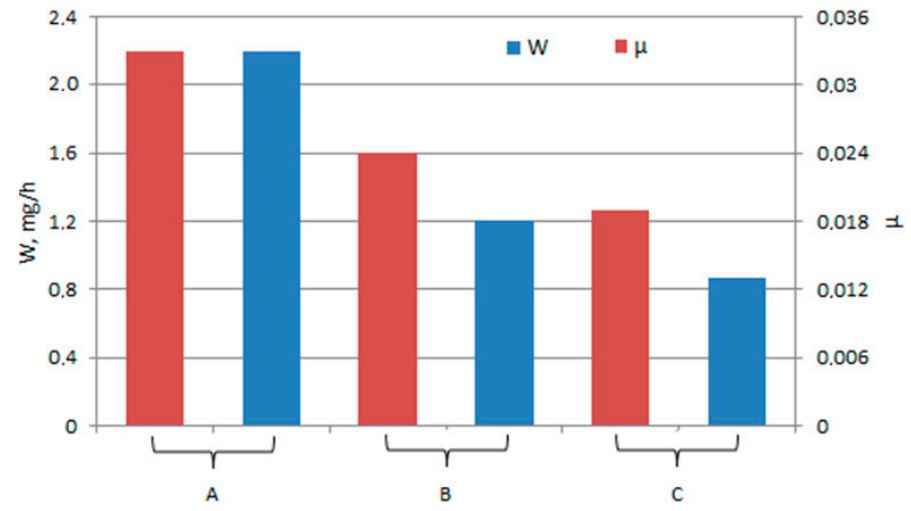

Figure 7. Wear rate of chrome-plated coatings in the friction pair with stuffing box seal and the value of the coefficient of friction: A-steel $40 \mathrm{KHN}$; B-chrome coating (quiet electrolyte); C-chrome coating (flowing electrolyte).

The results of tests of samples with chrome coatings in reciprocating motion showed that the coating reduces the wear rate of the chrome rod, which is operated in pair with the stuffing box seal of the rod installation. The combination of high microhardness of chrome coatings, as well as the specifics of the structure provide high wear resistance of chrome coatings applied from a flowing electrolyte. Chromium plating in a flowing electrolyte also reduces the coefficient of friction in the metal-polymer friction pair as 20 percent compared to chromium plating in a quite electrolyte. It is established that the minimum wear for reversible friction pair of electrochemical chrome coating-stuffing box seal is provided by the surface roughness of the coating Ra from 0.16 to $0.32 \mu \mathrm{m}$. All this ultimately increases the service life of pump parts, reduces the load on the mechanical part of the rod installation of the rocking machine, the cost of electricity to overcome the forces of thorns in the installation for rod production of oil from wells. In addition, the combination of ejector and plunger pumps for joint work increases the energy efficiency of oil production and ensures the rational use of potential energy of oil gas, as well as improving the environmental situation in oil fields, as it eliminates the combustion of oil gas.

The usage of the developed method to specify the rational placement of jet pumps in oil wells allows us to find the optimal operation mode of simultaneous operation of the sucker-rod pumps and the oil-gas jet pumps. This method will provide offtaking of the whole amount of free oil gas to enter the annulus of the well, and in turn it will provide the lowest possible stem load.

Results of this research are formulated in the form of a methodology for calculating the working parameters of a downhole ejection system, which is implemented in OGPD "Dolynanaftogaz" PJSC "Ukrnafta" and the methodology for determining the rational placement of oil-gas jet pumps in oil wells, approved by the PJSC "Ukrnafta", and the main design parameters of suggested jet pump for tandem installation in well 753-D as well as the exact place of its location in the well have been submitted for implementation.

This article does not really mention the effect of non-uniformity of the rod pump supply on the operation of the downhole ejector. We have conducted such studies, and they indicate that even at the minimum speed and flow rate of the working flow in the ejector (corresponding to the movement of the rods up) can suck the injected flow from the annulus of the well. In addition, for some wells it is advisable to use periodic ejector 
operation. This means that the gas will be removed from the annulus only when a certain critical pressure value is reached there.

The performed hydrodynamic calculations prove the efficiency of the proposed scheme of operation of the downhole jet pump and the rod pump in the well. Of course, the authors understand that this method of operation cannot be used for all oil wells and in each case it is necessary to justify the possibility of joint operation of the rod pump and ejector.

The novelty of the proposed study lays in a systematic approach to rod pump and our patented ejector pump operation in the oil well [85] and chrome plating of pump parts. The result of scientific research is a sound method of determining the rational location of the ejector in the oil well and the calculation of its geometry, which will provide a complete selection of petroleum gas released into the annulus of the oil well.

This will make possible obtaining the positive results, namely:

- $\quad$ effectively using the potential energy of free oil gas from annulus;

- making sucker-rod pump operation more stable;

- decreasing dynamic level fluctuations in the well (to avoid dangerous fluctuations in the case of a small immersion of the sucker-rod pump);

- $\quad$ increasing the production liquid to the surface by the mixed flow density reduction (after the jet pump);

- $\quad$ reducing the stem load, which in turn will extend their overhaul life;

- decreasing electricity consumption during well operation and decrease investments in oil production.

Especially this technology can show its efficiency in conditions of high gas-oil ratios and in regions with predominantly low ambient temperatures.

The results of industrial tests of jet and plunger pumps with reinforced chrome-plated parts showed an increase in their service life of about $27 \%$.

In further research, the authors plan to provide calculations considering the curvature of wellbores.

\section{Conclusions}

The study showed the following: the operation capability and efficiency of oil-gas jet pumps was proved, and the following conclusions were made:

It was established that the usage of low-pressure jet pumps with a cross-section areas ratio $f_{3} / f_{1}=6.25$ cannot provide a significant decrease in the outlet pressure of the suckerrod pump even with an increase in the installation depth due to the large difference inlet/outlet pressure of the jet pumps.

Furthermore, the minimum tubing load is specified by the combination of two factors: the minimum possible cross-section areas ratio $f_{3} / f_{1}$ and the maximal installation depth. This way, the ratio $f_{3} / f_{1}$ for the jet pumps is a factor to decrease significantly tubing loads. Depth of installation makes a much smaller effect if increased.

According to studies, the best operation mode for the 753-D oil well lays in the tandem installation (sucker-rod pump and the jet pump; $f_{3} / f_{1}=3$ and placed at depth $870 \mathrm{~m}$ ). This mode provides decreasing of outlet pressure of the sucker-rod pump up to $1.96 \mathrm{MPa}$.

This way, the authors recommend the following for the 753-D oil well OGPD "Dolynanaftogaz" PJSC "Ukrnafta":

- $\quad$ to install the high-pressure oil-gas jet pump $\left(f_{3} / f_{1}=3\right)$ at a depth of $870 \mathrm{~m}$ to take off the whole amount of free annulus gas. This means to aim at reducing the stem load by $26 \%$. The aforementioned jet pump has the following geometrical options: nozzle diameter $d_{n}=3.88 \mathrm{~mm}$, mixing chamber diameter $d_{m c}=6.72 \mathrm{~mm}$, and the diffuser outlet diameter $d_{d}=18.01 \mathrm{~mm}$.

Electrochemical chromium plating according to the developed technological process using an installation equipped with an automated control system of technological parameters of electrochemical chromium plating process in flowing electrolyte with nanoadditives, provided uniform coating with low surface roughness, high microhardness and wear resis- 
tance. The proposed innovations ensure the high quality of the working surfaces of parts and increase the performance of ejector and plunger pumps during oil production.

In addition, the usage of jet pumps will also improve the ecological situation in the oil production fields through the recycling of associated oil gas.

Author Contributions: Conceptualization, O.D., L.R. and O.B.; methodology, O.D. and M.S.; software, O.D. and T.P.; validation, O.D., L.R. and M.S.; formal analysis, O.D. and M.S.; investigation, O.D. and V.L.; resources, O.D. and L.R.; data curation, O.D. and M.S.; writing-original draft preparation, O.D., M.S. and V.L.; writing—review and editing, O.D., L.R., M.S. and V.L.; visualization, O.D., M.S., T.P. and V.L.; supervision, O.D. and L.R.; project administration, O.B. and L.R.; funding acquisition, O.B. All authors have read and agreed to the published version of the manuscript.

Funding: This study was carried out as part of the project "Belt and Road Initiative Institute for Chinese-European studies (BRIICES)" and was funded by the Guangdong University of Petrochemical Technology.

Institutional Review Board Statement: Not applicable.

Informed Consent Statement: Not applicable.

Data Availability Statement: Data are contained within the article.

Acknowledgments: The team of authors express their gratitude to the reviewers for valuable recommendations that have been taken into account to improve significantly the quality of this paper. The authors are grateful to the Ministry of Science and Education of Ukraine for the grant to implement the project D 8-21-P (RK 0121U109591).

Conflicts of Interest: The authors declare no conflict of interest.

\section{References}

1. Rajović, V.; Kiss, F.; Maravić, N.; Bera, O. Environmental flows and life cycle assessment of associated petroleum gas utilization via combined heat and power plants and heat boilers at oil fields. Energy Convers. Manag. 2016, 118, 96-104. [CrossRef]

2. IEA. World Energy Outlook. Flagship Report-2019; International Energy Agency: Paris, France, 2019; Available online: https: //www.iea.org/reports/world-energy-outlook-2019 (accessed on 20 May 2021).

3. Saik, P.; Petlovanyi, M.; Lozynskyi, V.; Sai, K.; Merzlikin, A. Innovative approach to the integrated use of energy resources of underground coal gasification. Solid State Phenom. 2018, 277, 221-231. [CrossRef]

4. Koltun, P.; Klymenko, V. Cradle-to-gate life cycle assessment of the production of separated mix of rare earth oxides based on Australian production route. Min. Miner. Depos. 2020, 14, 1-15. [CrossRef]

5. Pivnyak, G.; Bondarenko, V.; Kovalevska, I. New Developments in Mining Engineering 2015: Theoretical and Practical Solutions of Mineral Resources Mining; Taylor \& Francis: Abingdon, UK, 2015; 607p.

6. Le Billon, P.; Kristoffersen, B. Just cuts for fossil fuels? Supply-side carbon constraints and energy transition. Environ. Plan. A Econ. Space 2020, 52, 1072-1092. [CrossRef]

7. Krichevskiy, S. Evolution of technologies, "green" development and grounds of the general theory of technologies. Philos. Cosmol. 2015, 14, 120-139.

8. Khomenko, O.; Barna, T. Zonal-and-wave structure of open systems on micro, mega- and macrolevels of the universe. Philos. Cosmol. 2019, 22, 24-32. [CrossRef]

9. Rozin, V. From engineering and technological process to post-cultural technology. Future Hum. Image 2020, 15, 99-109. [CrossRef]

10. Akchiche, M.; Beauquin, J.-L.; Serra, S.; Sochard, S. Exergoeconomic Optimization of Oil and Gas Production Systems. In Proceedings of the SPE Europec Featured at 82nd EAGE Conference and Exhibition, virtual, 1-3 December 2020; pp. 1-15. [CrossRef]

11. Rabaev, R.U.; Belozerov, V.V.; Molchanova, V.A. Associated annular gas utilization methods. Pet. Eng. 2019, 17, 88-93. [CrossRef]

12. Anosike, N.; El-Suleiman, A.; Pilidis, P. Associated Gas Utilization Using Gas Turbine Engine, Performance Implication-Nigerian Case Study. Energy Power Eng. 2016, 8, 137-145. [CrossRef]

13. Pavlychenko, A.; Kovalenko, A. The investigation of rock dumps influence to the levels of heavy metals contamination of soil. In Mining of Mineral Deposits; CRC Press: Boca Raton, FL, USA, 2013; pp. 237-238. [CrossRef]

14. Pujihatma, P.; Hadi, S.P.; Rohmat, T.A. Combined heat and power-multi-objective optimization with an associated petroleum and wet gas utilization constraint. J. Nat. Gas Sci. Eng. 2018, 54, 25-36. [CrossRef]

15. Law, B.E.; Ulmishek, G.F.; Clayton, J.L.; Kabyshev, B.P.; Pashova, N.T.; Krivosheya, V.A. Basin-centered gas evaluated in Dnieper-Donets basin, Donbas foldbelt, Ukraine. Oil Gas J. 1998, 96, 74-78.

16. Fyk, M.; Biletskyi, V.; Abbood, M.; Al-Sultan, M.; Abbood, M.; Abdullatif, H.; Shapchenko, Y. Modeling of the lifting of a heat transfer agent in a geothermal well of a gas condensate deposit. Rozrobka Rodovyshch 2020, 14, 66-74. [CrossRef] 
17. Panevnyk, D.O.; Panevnyk, O.V. Investigation of the joint work of a jet and plunger pump with a balancing crank-rod drive. Neftyanoe Khozyaystvo Oil Ind. 2020, 2, 58-61. [CrossRef]

18. Panevnyk, O.V.; Dubei, O.Y. Determination of the pressure and temperature distribution along the oil well bore. Nauk. Visnyk Natsionalnoho Hirnychoho Universytetu 2015, 148, 98-103.

19. Bekbergenov, D.; Jangulova, G.; Kassymkanova, K.K.; Bektur, B. Mine technical system with repeated geotechnology within new frames of sustainable development of underground mining of caved deposits of the Zhezkazgan field. Geod. Cartogr. 2020, 46, 182-187. [CrossRef]

20. Drozdov, A.; Gorbyleva, Y. Improving the Operation of Pump-ejector Systems at Varying Flow Rates of Associated Petroleum Gas. J. Min. Inst. 2019, 238, 415-422. [CrossRef]

21. Gabdrkhmanova, K.; Izmailova, G.; Samigullina, L. Solution of the Problem of Annular Space Gas Utilization in Wells Operated by Walking-Beam Pumping Unit. IOP Conf. Ser. Earth Environ. Sci. 2020, 459, 042080. [CrossRef]

22. Telkov, V.P. Improvement of oil recovery by jet and electrical centrifugal pumping technology of water/gas influence. In Proceedings of the SPE Annual Technical Conference and Exhibition, Anaheim, CA, USA, 11-14 November 2007; pp. 4-9. [CrossRef]

23. Yelemessov, K.; Krupnik, L.; Bortebayev, S.; Beisenov, B.; Baskanbayeva, D.; Igbayeva, A. Polymer concrete and fibre concrete as efficient materials for manufacture of gear cases and pumps. E3S Web Conf. 2020, 168, 00018. [CrossRef]

24. Prokopenko, D.; Shatskyi, I.; Vorobiov, M.; Ropyak, L. Cyclic deformation of separating tape in electromagnetic rolling pump. J. Phys. Conf. Ser. 2021, 1741, 012029. [CrossRef]

25. Tarel'nik, V.B.; Konoplyanchenko, E.V.; Kosenko, P.V.; Martsinkovskii, V.S. Problems and Solutions in Renovation of the Rotors of Screw Compressors by Combined Technologies. Chem. Petrol Eng. 2017, 53, 540-546. [CrossRef]

26. Sun, T.; Zhang, X.; Liu, S.; Cao, Y.; Xie, R. Annular Pressure Buildup Calculation When Annulus Contains Gas. Chem. Technol. Fuels Oils 2018, 54, 484-492. [CrossRef]

27. Jianxin, S. Application of composite jet-rod pumping system in a system in a deep heavy-oil field in Tarim China. In Proceedings of the SPE Annual Technical Conference and Exhibition, Florence, Italy, 19-22 September 2010; p. 8. [CrossRef]

28. Drozdov, A.N.; Drozdov, N.A. Prospects of development of jet pump's well operation technology in Russia. In Proceedings of the SPE Russian Petroleum Technology Conference, Moscow, Russia, 26-28 October 2015; pp. 1-14. [CrossRef]

29. Fedorov, A.E.; Verbitsky, V.S.; Goridko, K.A. Experimental studies and analysis of gas-jet device's operation characteristics for oil and gas production in abnormal operating conditions. In Proceedings of the SPE Russian Petroleum Technology Conference and Exhibition, Moscow, Russia, 24-26 October 2016. [CrossRef]

30. Skitsa, L.; Yatsyshyn, T.; Liakh, M.; Sydorenko, O. Ways to improve safety of a pumping-circulatory system of a drilling rig. Min. Miner. Depos. 2018, 12, 71-79. [CrossRef]

31. Velichkovich, A.S. Shock absorber for oil-well sucker-rod pumping unit. Chem. Pet. Eng. 2005, 41, 544-546. [CrossRef]

32. Moysyshyn, V.M.; Lyskanych, M.V.; Borysevych, L.V.; Zhovniruk, R.A. Multifactorial Empirical Model of Three-Cone Bit Gear Oscillation Energy. Metallofiz. Noveishie Tekhnol. 2020, 42, 1729-1752. [CrossRef]

33. Velychkovych, A.; Petryk, I.; Ropyak, L. Analytical study of operational properties of a plate shock absorber of a sucker-rod string. Shock Vib. 2020, 2020, 3292713. [CrossRef]

34. Zhang, T.; Zhang, N. Vibration Modes and the Dynamic Behaviour of a Hydraulic Plunger Pump. Shock Vib. 2016, $2016,9679542$. [CrossRef]

35. Moisyshyn, V.M.; Lyskanych, M.V.; Borysevych, L.V.; Kolych, N.B.; Zhovniruk, R.A. Integral Indicators of Change of Drilling Column Vibration-Criterion for Assessing of Roller Cone Bit Wear. Metallofiz. Noveishie Tekhnol. 2019, 41, 1087-1102. [CrossRef]

36. Dutkiewicz, M.; Gołębiowska, I.; Shatskyi, I.; Shopa, V.; Velychkovych, A. Some aspects of design and application of inertial dampers. MATEC Web Conf. 2018, 178, 06010. [CrossRef]

37. Velichkovich, A.S.; Velichkovich, S.V. Vibration-impact damper for controlling the dynamic drillstring conditions. Chem. Pet. Eng. 2001, 37, 213-215. [CrossRef]

38. Shatskyi, I.; Velychkovych, A. Increase of compliance of shock absorbers with cut shells. IOP Conf. Ser. Mater. Sci. Eng. 2019, 564, 012072. [CrossRef]

39. Ropyak, L.Y.; Velychkovych, A.S.; Vytvytskyi, V.S.; Shovkoplias, M.V. Analytical study of "Crosshead-Slide rail" wear effect on pump rod stress state. J. Phys. Conf. Ser. 2021, 1741, 012039. [CrossRef]

40. Li, W.; Dong, S.; Sun, X. An Improved Sucker Rod Pumping System Model and Swabbing Parameters Optimized Design. Math. Probl. Eng. 2018, 2018, 4746210. [CrossRef]

41. Konoplianchenko, I.; Tarelnyk, V.; Martsynkovskyy, V.; Gaponova, O.; Lazarenko, A.; Sarzhanov, A.; Mikulina, M.; Zhengchuan, Z.; Pirogov, V. New technology for restoring Babbitt coatings. J. Phys. Conf. Ser. 2021, 1741, 012040. [CrossRef]

42. Kalwar, S.A.; Awan, A.Q.; Qureshi, F.A. Optimum selection and application of hydraulic jey pump for well-1A: A case study. In Proceedings of the Abu Dhabi International Petroleum Exhibition \& Conference, Abu Dhabi, United Arab Emirates, 13-16 November 2017. [CrossRef]

43. Zhautikov, B.A.; Aikeyeva, A.A. Development of the system for air gap adjustment and skip protection of electromagnetic lifting unit. J. Min. Inst. 2018, 229, 62-69. [CrossRef] 
44. Kumar, S.; Kalwar, S.A.; Farouque, K.; Qureshi, S.; Anjum, Z.A. Production enhancement by installation of jet pump in SSD in Pakistan Ghauri Oil Field. In Proceedings of the SPE Middle East Artificial Lift Conference and Exhibition, Manama, Bahrain, 30 November-1 December 2016. [CrossRef]

45. Kurkjian, A.L. Optimazing jet-pump production in the presence of gas. SPE Prod. Oper. 2018, 34, 373-384. [CrossRef]

46. Panevnik, D.A.; Velichkovich, A.S. Assessment of the stressed state of the casing of the above-bit hydroelevator. Neftyanoe Khozyaystvo-Oil Ind. 2017, 1, 70-73.

47. Shatskyi, I.; Popadyuk, I.; Velychkovych, A. Hysteretic Properties of Shell Dampers. In Dynamical Systems in Applications; Springer Proceedings in Mathematics \& Statistics Book Series; Springer: Berlin/Heidelberg, Germany, 2018; Volume 249, pp. 343-350. [CrossRef]

48. Velichkovich, A.; Dalyak, T.; Petryk, I. Slotted shell resilient elements for drilling shock absorbers. Oil Gas Sci. Technol.-Rev. IFP Energ. Nouv. 2018, 73, 34. [CrossRef]

49. Shats'kyi, I.P.; Makoviichuk, M.V. Contact Interaction of Crack Lips in Shallow Shells in Bending with Tension. Mater. Sci. 2005, 41, 486-494. [CrossRef]

50. Velichkovich, A.S.; Popadyuk, I.I.; Shopa, V.M. Experimental study of shell flexible component for drilling vibration damping devices. Chem. Petrol. Eng. 2011, 46, 518-524. [CrossRef]

51. Mikhlin, Y.V.; Zhupiev, A.L. An application of the ince algebraization to the stability of non-linear normal vibration modes. Int. J. Non-Linear Mech. 1997, 32, 393-409. [CrossRef]

52. Kopei, V.; Onysko, O.; Panchuk, V. The Application of the Uncorrected Tool with a Negative Rake Angle for Tapered Thread Turning. In Advances in Design, Simulation and Manufacturing II; Springer: Cham, Switzerland, 2020; pp. 149-158. [CrossRef]

53. Onysko, O.R.; Kopey, V.B.; Panchuk, V.G. Theoretical investigation of the tapered thread joint surface contact pressure in the dependence on the profile and the geometric parameters of the threading turning tool. IOP Conf. Ser. Mater. Sci. Eng. 2020, 749, 012007. [CrossRef]

54. Pryhorovska, T.; Ropyak, L. Machining Error Influnce on Stress State of Conical Thread Joint Details. In Proceedings of the IEEE 8th International Conference on Advanced Optoelectronics and Lasers (CAOL), Sozopol, Bulgaria, 6-8 September 2019; Volume 9019544, pp. 493-497. [CrossRef]

55. Onysko, O.; Kopei, V.; Medvid, I.; Pituley, L.; Lukan, T. Influence of the Thread Profile Accuracy on Contact Pressure in Oil and Gas Pipes Connectors. In Advances in Design, Simulation and Manufacturing III; Lecture Notes in Mechanical Engineering Book Series; Springer: Cham, Switzerland, 2020; pp. 432-441. [CrossRef]

56. Tutko, T.; Dubei, O.; Ropyak, L.; Vytvytskyi, V. Determination of Radial Displacement Coefficient for Designing of Thread Joint of Thin-Walled Shells. In Advances in Design, Simulation and Manufacturing IV; Lecture Notes in Mechanical Engineering Book Series; Springer: Cham, Switzerland, 2021; pp. 153-162. [CrossRef]

57. Onysko, O.; Kopei, V.; Panchuk, V.; Medvid, I.; Lukan, T. Analytical study of kinematic rake angles of cutting edge of lathe tool for tapered thread manufacturing. In Advanced Manufacturing Processes; Lecture Notes in Mechanical Engineering Book Series; Springer: Cham, Switzerland, 2020; pp. 236-245. [CrossRef]

58. Shatskyi, I.; Ropyak, L.; Velychkovych, A. Model of contact interaction in threaded joint equipped with spring-loaded collet. Eng. Solid Mech. 2020, 8, 301-312. [CrossRef]

59. Ropyak, L.Y.; Vytvytskyi, V.S.; Velychkovych, A.S.; Pryhorovska, T.O.; Shovkoplias, M.V. Study on grinding mode effect on external conical thread quality. IOP Conf. Ser. Mater. Sci. Eng. 2021, 1018, 012014. [CrossRef]

60. Piotter, V.; Klein, A.; Plewa, K. Development of a ceramic injection molding process for liquid jet nozzles to be applied for X-ray free-electron lasers. Microsyst. Technol. 2018, 24, 1247-1252. [CrossRef]

61. Zhang, F.L. Machining Mechanism of Abrasive Water Jet on Ceramics. Key Eng. Mater. 2010, 426, 212-215. [CrossRef]

62. Ropyak, L.; Ostapovych, V. Optimization of process parameters of chrome plating for providing quality indicators of reciprocating pumps parts. East.-Eur. J. Enterp. Technol. 2016, 80, 50-62. [CrossRef]

63. Snizhko, L.O.; Yerokhin, A.; Gurevina, N.L.; Ciba, A.V.; Matthews, A. Voltastatic studies of magnesium anodising in alkaline solutions. Surf. Coat. Technol. 2010, 205, 1527-1531. [CrossRef]

64. Dzyubyk, A.; Sudakov, A.; Dzyubyk, L.; Sudakova, D. Ensuring the specified position of multisupport rotating units when dressing mineral resources. Rozrobka Rodovyshch 2019, 13, 91-98. [CrossRef]

65. Shatskii, I.P. Tension of a plate containing a rectilinear cut with hinged rims. J. Appl. Mech. Techn. Phys. 1989, 30, 828-830. [CrossRef]

66. Shatskyi, I.P.; Makoviichuk, M.V.; Shcherbii, A.B. Equilibrium of cracked shell with flexible coating. In Shell Structures: Theory and Applications; Taylor \& Francis Group: Abingdon, UK, 2018; Volume 4, pp. 165-168. [CrossRef]

67. Ropyak, L.Y.; Shatskyi, I.P.; Makoviichuk, M.V. Influence of the Oxide-Layer Thickness on the Ceramic-Aluminium Coating Resistance to Indentation. Metallofiz. Noveishie Tekhnologii 2017, 39, 517-524. [CrossRef]

68. Ropyak, L.; Schuliar, I.; Bohachenko, O. Influence of technological parameters of centrifugal reinforcement upon quality indicators of parts. East.-Eur. J. Enterp. Technol. 2016, 79, 53-62. [CrossRef]

69. Shatskyi, I.P.; Ropyak, L.Y.; Makoviichuk, M.V. Strength optimization of a two-layer coating for the particular local loading conditions. Strength Mater. 2016, 48, 726-730. [CrossRef]

70. Sudakov, A.; Dreus, A.; Kuzin, Y.; Sudakova, D.; Ratov, B.; Khomenko, O. A thermomechanical technology of borehole wall isolation using a thermoplastic composite material. E3S Web Conf. 2019, 109, 00098. [CrossRef] 
71. Sudakov, A.; Dreus, A.; Ratov, B.; Delikesheva, D. Theoretical bases of isolation technology for swallowing horizons using thermoplastic materials. News Natl. Acad. Sci. Repub. Kazakhstan Ser. Geol. Tech. Sci. 2018, 428, 72-80.

72. Sudakov, A.K.; Khomenko, O.Y.; Isakova, M.L.; Sudakova, D.A. Concept of numerical experiment of isolation of absorptive horizons by thermoplastic materials. Nauk. Visnyk Natsionalnoho Hirnychoho Universytetu 2016, 5, 12-16.

73. Sudakov, A.; Dreus, A.; Sudakova, D.; Khamininch, O. The study of melting process of the new plugging material at thermomechanical isolation technology of permeable horizons of mine opening. E3S Web Conf. 2018, 60, 00027. [CrossRef]

74. Bloch, H.P.; Geitner, F.K. Protecting machinery parts against the loss of surface. In Machinery Component Maintenance and Repair; Elsevier: Amsterdam, The Netherlands, 2019; pp. 551-633. [CrossRef]

75. Ropyak, L.Y.; Shatskyi, I.P.; Makoviichuk, M.V. Analysis of interaction of thin coating with an abrasive using one-dimensional model. Metallofiz. Noveishie Tekhnologii 2019, 41, 647-654. [CrossRef]

76. Shatskyi, I.P.; Perepichka, V.V.; Ropyak, L.Y. On the influence of facing on strength of solids with surface defects. Metallofiz. Noveishie Tekhnologii 2020, 42, 69-76. [CrossRef]

77. Bazaluk, O.; Lozynskyi, V.; Falshtynskyi, V.; Saik, P.; Dychkovskyi, R.; Cabana, E. Experimental Studies of the Effect of Design and Technological Solutions on the Intensification of an Underground Coal Gasification Process. Energies 2021, 14, 4369. [CrossRef]

78. Falshtynskyi, V.S.; Dychkovskyi, R.O.; Lozynskyi, V.G.; Saik, P.B. Determination of the Technological Parameters of Borehole Underground Coal Gasification for Thin Coal Seams. J. Sustain. Min. 2013, 12, 8-16. [CrossRef]

79. Ovetska, O.; Ovetskyi, S.; Vytiaz, O. Conceptual principles of project management for development of hydrate and other unconventional gas fields as a component of energy security of Ukraine. E3S Web Conf. 2021, 230, 01021. [CrossRef]

80. Bazaluk, O.; Slabyi, O.; Vekeryk, V.; Velychkovych, A.; Ropyak, L.; Lozynskyi, V. A technology of hydrocarbon fluid production intensification by productive stratum drainage zone reaming. Energies 2021, 14, 3514. [CrossRef]

81. Mei, W. Surface jet ump trial test in Safania Field: Evaluation and case study. In Proceedings of the SPE Kingdom of Saudi Arabia Annual Technical Symposium and Exhibition, Dammam, Saudi Arabia, 24-27 April 2017. [CrossRef]

82. Dubei, O.Y.; Panevnyk, O.V. Basic equation of the low-pressure oil-gas jet. Mod. Eng. Innov. Technol. 2017, 2, 7-15. [CrossRef]

83. Humeniuk, A.I.; Popadyuk, O.Y.; Ropyak, L.Y.; Kostyk, V.V. Method for Cleaning Air from Mechanical Particles, Microbes and Viruses. Ukrainian Patent Application No. u202002929; International Patent Application No. IPC/B01D47/02. 15 May 2020. Available online: https:/ / sis.ukrpatent.org/en/search/detail/1447618/ (accessed on 15 October 2021).

84. Dubei, O.Y. Analytical study of the efficient operation modes of oil-gas jet pumps used in oil wells. AGH Drill. Oil Gas 2019, 36, 19-29. [CrossRef]

85. Panevnik, O.V.; Dubey, O.Y.; Yaremko, I.Y.; Lyakh, M.M. Well Ejector. Ukrainian Patent Application No. a201307030; International Patent Application No. IPC/F05B47/02; Ukrainian Patent No. 105135. 4 June 2013. Bul. No. 7/2014, Published on 10 April 2014. Available online: https:/ / sis.ukrpatent.org/uk/search/detail/1018049/ (accessed on 15 October 2021).

86. Dubei, O.Y. Improving the Efficiency of the Sucker Rod Pump Units by Using Oil-Gas Jets. Dissertation for Technical Sciences Candidate's Degree in Specialty 05.05.12-Machines of Oil and Gas Industry, Ivano-Frankivsk National Technical University of Oil and Gas, Ivano-Frankivsk, Ukraine, 2016; 218p. Available online: https:/ / old.nung.edu.ua/files/attachments/disertaciya_ dubey.pdf (accessed on 15 October 2021).

87. Dubei, O.Y. Rivnyannya visokonapirnogo naftogazovogo ezhektora. In Proceedings of the Internet Symposium "Scientific Answers to the Challenges of Modernity-2016"; Volume 2, pp. 107-126. Available online: https://www.sworld.com.ua/ simpoz6/25.pdf (accessed on 15 October 2021).

88. Ropyak, L.Y.; Shovkoplias, M.V.; Vytvytskyi, V.S. Determination of machining allowance for parts with chimney. Bull. Cherkasy State Technol. Univ. 2021, 2, 117-127. [CrossRef] 